University of Nebraska - Lincoln

DigitalCommons@University of Nebraska - Lincoln

Educational Psychology Papers and

Publications

Educational Psychology, Department of

2011

Adolescents Are Young Adults, Not Immature Brains

David Moshman

Follow this and additional works at: https://digitalcommons.unl.edu/edpsychpapers

Part of the Child Psychology Commons, Cognitive Psychology Commons, Developmental Psychology Commons, and the School Psychology Commons

This Article is brought to you for free and open access by the Educational Psychology, Department of at DigitalCommons@University of Nebraska - Lincoln. It has been accepted for inclusion in Educational Psychology Papers and Publications by an authorized administrator of DigitalCommons@University of Nebraska - Lincoln. 


\title{
Adolescents Are Young Adults, Not Immature Brains
}

\author{
David Moshman \\ University of Nebraska-Lincoln \\ Correspondence - David Moshman, Educational Psychology, University of Nebraska, \\ Lincoln, NE 68588-0345; email dmoshman1@unl.edu
}

When G. Stanley Hall (1904) wrote the first book on adolescence at the turn of the 2oth century, he was describing a new cultural phenomenon that had emerged in the United States and other industrializing societies during the late 19th century. There had always been children, whether or not we theorized about them, but there had not always been adolescents.

Of course, there have always been teenagers in the mathematical sense of persons who have reached the age of 13 years but not yet 20 years (and in the linguistic sense that these are the "teen" years in our counting scheme). But in most societies and cultural traditions teenagers were not a distinguishable group. Depending on gender they might be expected to work, marry, have children, or run a household. The Jewish Bar Mitzvah at age 13, for example, has for centuries marked entry into the adult community with full rights and responsibilities. Romeo's Juliet was just 13 years old. Teens were young adults for most of history; there was no special category of teenagers or adolescents.

Published in Applied Developmental Science 15:4 (2011), pp 171-174.

doi:10.1080/10888691.2011.618098

Copyright (C) 2011 Taylor \& Francis Group, LLC. Used by permission. 
Now that adolescents have been around for more than a century, however, we think they have been here forever. In fact, we theorize about them as if adolescence were a natural biological phenomenon associated with the teen years, and as if the psychological phenomena of adolescence were the predictable result of teen brains.

Our thinking about adolescents, I suggest, is deeply flawed. In this guest editorial, expanding on previous publications (Moshman, 2011a, 2011b, 2011c), I identify five fallacies.

\section{Categorical misclassification}

Teenagers (ages 13-19) are categorically different from young children but not from older individuals. Teens routinely show forms and levels of knowledge and reasoning rarely or never seen before the age of 10 or 11 . Like adults, but unlike children, those we call "adolescents" often engage in hypothetico-deductive reasoning, dialectical reasoning, and reflective coordinations of theories and evidence. They show explicit conceptions of inferential validity and reflective epistemologies. In social and moral contexts they apply third-party perspective taking and principled reasoning. Many construct personal identities (Moshman, 2011a; see also Kuhn, 2009).

There is no comparable list, to my knowledge, of abilities common among older individuals but rare in young teens. Anything most adults can do, most teens can do too. Development beyond the age of about 12 is far too subtle and individualized to divide people into categories on the basis of age.

It is thus a misclassification to categorize adolescents with children (as "minors" or "mere children"). There is, moreover, no reason to see them as constituting a distinct category between children and adults. There is simply no empirical basis for categorically distinguishing adolescents from adults.

\section{Alleged irrationalities}

Regardless of the evidence for adolescent competence, allegations of adolescent irrationality never end. In the latter third of the 2oth century, a favored concept was "adolescent egocentrism," which was taken to include uniquely adolescent tendencies to construct a "personal fable" of oneself and assume an "imaginary audience" especially concerned with that self. For decades after Elkind's (1967) theoretical analysis of egocentrism in relation to Piaget's stage of formal operations, it was popular to talk of "adolescent egocentrism" as if there were some special kind or extent of egocentrism associated with adolescence. Substantial research, however, has 
failed to show the age trends predicted by Elkind's theoretical claims (Millstein \& Halpern-Felsher, 2002; Quadrel, Fischhoff,\&Davis, 1993; Smetana \& Villalobos, 2009). We are all egocentric in various ways and to various degrees. The egocentrism of adolescents is nothing special.

Today the latest concern is "adolescent risk taking," which is taken to be a bad thing special to adolescents. It is often rational to take risks, however, and adolescence is a period of life when this is surely so. Do adolescents have a special propensity, rarely seen in children or adults, to take irrational risks? On the contrary, adolescents take the same sorts of risks as adults and show the same rational and irrational tendencies common to human functioning. There is no empirical basis for distinguishing adolescents from adults with respect to risk taking.

Of course many adolescents repeatedly engage in behaviors (often involving drugs or sex) that many adults find objectionable, but many adults also engage in the same behaviors. There is no standard of rational risk taking that is generally met by adults but rarely by adolescents (Moshman, 2011a). Beyond about age 12, individual differences in how open we are to taking risks and how rational we are in assessing risk have little or no relation to age. Other factors such as poverty may be more strongly related to the propensity to take risks and the types of risks taken (Males, 2009, 2010a).

Are adolescents irrational? The evidence is clear that they often fall short of logical and other standards of rationality and that they are highly subject to emotional biases, cognitive distortions, self-serving denial, and peer pressure. But, adults are irrational in all the same ways and, on average, to about the same extent. Beyond about age 12, age does not predict rationality.

\section{False charges of immaturity}

Children of any age up to 12 are demonstrably more mature than children three years younger than themselves. The literature of developmental psychology provides many examples of competencies routinely seen among, say, 6-year-olds that are rare among 3-year-olds. And, even 9-year-olds are lacking a variety of competencies most of them will show by the age of 12. But, there is no evidence of any form or level of competence common among adults beyond some age but rare in young teens. Quite the contrary, on any measure of competence, rationality, or psychological functioning, many 14-yearolds perform beyond the level of many 40-year-olds (Moshman, 2011a).

In recent years, terms such as "executive function" and "executive control" have been used to refer to higherorder forms of information processing involving metacognitive self-regulation. But children, it is important 
to emphasize, show executive function and control from early ages. Young teens have attained levels not seen in early childhood but individual differences beyond early adolescence show little or no relation to age. There is no adult level of executive function or control that adolescents have yet to attain (Spear, 2010).

This is not to say there is no development beyond age 12. Quite the contrary, developmental progress in reasoning, rationality, morality, and identity over the teen years and beyond is common (Moshman, 2011a). But, development beyond age 12 is highly individualized. Adolescents develop to varying degrees in diverse domains and cultural contexts. Individual differences beyond age 12 are substantial, but age accounts for very little of the variance.

\section{Reductionism}

Brain science has become increasingly popular since the 1990s, and this is especially true of research on adolescent brains (e.g., Casey, Getz, \& Galvan, 2008; Spear, 2010). The potential value of such research is obvious. But interpretations of results, especially in the popular press, have tended to reduce psychology to neurobiology. The brain is presented as if it causes (and thus explains) behavior. We are, in the reductionist view, our brains.

However, we are more than our brains, and what we do is not simply done by our brains. We are complex, self-regulating organisms interacting with other such organisms in complex and changing environments. More generally, wholes are greater than the sums of their parts. Brains are more than neurons or genes and people are more than brains.

Reductionism is arguably a fallacy in principle (Gottlieb, Wahlsten, \& Lickliter, 2006; Hood, Halpern, Greenberg, \& Lerner, 2010; Overton, 2006, 2010). As we move from physics to chemistry to biology to psychology to sociology, new phenomena emerge that require new forms of explanation. Combinations of atoms generate chemical phenomena that are consistent with the laws of physics but cannot be fully explained by the physics of atoms. As the chemistry of carbon moves into the realm of biochemistry it yields phenomena of life that, without defying the laws of chemistry, sufficiently transcend them to require new, biological forms of explanation. The behavior of organisms, in turn, is entirely biological, but requires psychological explanation in terms of individual agency and information processing. Psychological phenomena cannot be reduced to the anatomy and physiology of brains. 
Even if reduction were possible in principle, moreover, we are a long way from achieving it in fact. The behavior of diverse organisms in diverse environmental contexts cannot be predicted accurately from knowledge of biology and context. The potential interactions of various biological and contextual factors are far beyond our knowledge and likely beyond human comprehension. In particular, we know far too little about the relation of brain to behavior to explain the latter by the former.

One especially disturbing recent trend is the tendency to reduce sociology directly to neurobiology, bypassing psychology entirely. Brain explanations of risk taking fall in this category in that they seek a biological explanation for a vaguely conceptualized social phenomenon that has little psychological reality. At the psychological level, as we have seen, there is no such thing as "adolescent risk taking" except in the trivial sense that adolescents, like children and adults, take a variety of risks, sometimes wisely and sometimes not. However, regardless of the psychological evidence, adolescent risk taking is seen as a social and cultural problem that needs to be addressed. If we cannot find anything uniquely wrong in adolescent minds, we look to their brains.

\section{Determinism}

Determinism, which is closely related to reductionism, explains the current state of a developing or developed organism as caused by genes, culture, or some other specific factor, thus either denying the developmental process or attributing development to the direct causal effect of that factor. Forces beyond our control change our brains, a determinist would argue, and thus change us. We become whatever our brains become when they get changed.

Determinism is rejected by most developmentalists (Hood et al., 2010; Overton, 2006, 2010; Paus, 2009), especially proponents of constructivism (Mu“ ller, Carpendale, \& Smith, 2009), dynamic systems (Witherington, 2007, 2011), and relational developmental systems (Gottlieb et al., 2006; Lerner, 2006; Overton, 2010). In particular, extensive research has disconfirmed deterministic views in which genes cause brain maturation which, in turn, causes the emergence of 
new cognitive abilities or levels of functioning. In general, it is equally plausible that adolescent activities and experiences cause cognitive progress which, in turn, causes positive changes in the structure and functioning of the brain (Paus, 2009).

We need not ask, however, whether brain changes are caused by genes, environments, or mental actions. To concern ourselves with what causes what, in what order, would invoke the physical causality of billiard balls. The developmental causality of biological organisms has been variously described as bidirectional, relational, reciprocal, circular, co-active, and pluralistic. The brain is part of a larger self-regulating biological system that in turn plays an active role in a social and physical environment. We transform our brains and our environments even as they transform us. Development cannot be understood as a simple succession of causes and effects.

Determinism is seen by many as scientific in its reductionism. Reductionist explanations, however, rely on simple forms of causality that cannot explain developing biological and psychological structures and processes (Witherington, 2011). The adolescent brain has great potential, but it cannot depend on genes to generate development.

\section{Conclusion}

The evidence to support a view of adolescents as young adults is substantial. Conceptualizations of adolescents that highlight their rational agency and competence come from many quarters (Barber, 2009; Benson, 2008; Daiute, 2010; Damon, 2008; Epstein, 2010; Hammack, 2011; Hine, 1999; Kuhn, 2009; Lerner, 2004, 2007; Levesque, 2000, 2007; Males, 2009, 2010a, 2010b; Macleod, 2011; Millstein \& Halpern-Felsher, 2002; Moshman, 1993, 2009, 2011a, 2011b; Nichols \& Good, 2004; Quadrel et al., 1993; Sercombe, 2010; Sherrod, TorneyPurta, \& Flanagan, 2010; Smetana, 2011; Smetana \& Villalobos, 2009; Umeh, 2009).

To see adolescents instead as irrational brains on the road to rational maturity is to succumb to all the fallacies discussed previously. Adolescents are rational agents interacting with each other and with their environments and constructing their own futures. They cannot do this without their brains, but they are constructing their brains, 
not simply being driven by them. Adolescents may indeed develop, but their development is not caused by their brains. Adolescents may become more rational, but there is no universal or biological state of maturity waiting to be reached.

Adolescents are, in other words, young adults. They may have greater developmental potential than older adults, but the possibility of developmental change does not end with adolescence and does not make adolescents children. Adolescents, like adults but unlike children, may or may not develop, depending in part on their circumstances. The challenge for research is to understand what potentially develops beyond childhood and how. The challenge for practice is to promote such development where we can.

\section{References}

Barber, B. K. (Ed.). (2009). Adolescents and war: How youth deal with political violence. Oxford, UK: Oxford University Press.

Benson, P. L. (2008). Sparks: How parents can help ignite the hidden strengths of teenagers. San Francisco, CA: Jossey-Bass.

Casey, B. J., Getz, S., \& Galvan, A. (2008). The adolescent brain. Developmental Review, 28, 62-77. DOI: 10.1016/j.dr.2007.08.003

Daiute, C. (2010). Human development and political violence. New York, NY: Cambridge University Press.

Damon, W. (2008). The path to purpose: How young people find their calling in life. New York, NY: Free Press.

Elkind, D. (1967). Egocentrism in adolescence. Child Development, 38, 1025-1034.

Epstein, R. (2010). Teen 2.0: Saving our children and families from the torment of adolescence. San Jose, CA: Quill Driver Books.

Gottlieb, G., Wahlsten, D., \& Lickliter, R. (2006). The significance of biology for human development: A developmental psychobiological systems perspective.

In W. Damon, R. M. Lerner (Series Eds.) \& R. M. Lerner (Vol. Ed.), Handbook of child psychology: Vol. 1. Theoretical models of human development (6th ed., pp. 210-257). Hoboken, NJ: Wiley.

Hall, G. S. (1904). Adolescence. New York, NY: Appleton.

Hammack, P. L. (2011). Narrative and the politics of identity: The cultural psychology of Israeli and Palestinian youth. New York, NY: Oxford University Press.

Hine, T. (1999). The rise and fall of the American teenager. New York, NY: HarperCollins. 
Hood, K. E., Halpern, C. T., Greenberg, G., \& Lerner, R. M. (Eds.). (2010). Handbook of developmental science, behavior, and genetics. Malden, MA: Wiley-Blackwell.

Kuhn, D. (2009). Adolescent thinking. In R. M. Lerner \& L. Steinberg (Eds.), Handbook of adolescent psychology, Vol. 1 ( 3rd ed., pp. 152- 186). Hoboken, NJ: Wiley.

Lerner, R. M. (2004). Liberty: Thriving and civic engagement among America's youth. Thousand Oaks, CA: Sage.

Lerner, R. M. (2006). Developmental science, developmental systems, and contemporary theories of human development. In W. Damon, R. M. Lerner (Series Eds.) \& R. M. Lerner (Vol. Ed.), Handbook of child psychology: Vol. 1. Theoretical models of human development (6th ed., pp. 1-17). Hoboken, NJ: Wiley.

Lerner, R. M. (2007). The good teen: Rescuing adolescence from the myths of the storm and stress years. New York, NY: Three Rivers Press.

Levesque, R. J. R. (2000). Adolescents, sex, and the law: Preparing adolescents for responsible citizenship. Washington, DC: American Psychological Association.

Levesque, R. J. R. (2007). Adolescents, media, and the law: What developmental science reveals and free speech requires. New York, NY: Oxford University Press.

Macleod, C. I. (2011). “Adolescence,” pregnancy and abortion: Constructing a threat of degeneration. New York, NY: Routledge.

Males, M. (2009). Does the adolescent brain make risk taking inevitable? A skeptical appraisal. Journal of Adolescent Research, 24, 3-20. DOI: 10.1177/0743558408326913

Males, M. A. (2010a). Is jumping off the roof always a bad idea? A rejoinder on risk taking and the adolescent brain. Journal of Adolescent Research, 25, 48-63. DOI: $10.1177 / 0743558409353780$

Males, M. (2010b). Teenage sex and pregnancy: Modern myths, unsexy realities. Santa Barbara, CA: Praeger.

Millstein, S. G., \& Halpern-Felsher, B. L. (2002). Judgments about risk and perceived invulnerability in adolescents and young adults. Journal of Research on Adolescence, 12, 399-422.

Moshman, D. (1993). Adolescent reasoning and adolescent rights. Human Development, 36, 27-40. DOI: 10.1159/000277287

Moshman, D. (2009). Liberty and learning: Academic freedom for teachers and students. Portsmouth, NH: Heinemann.

Moshman, D. (2011a). Adolescent rationality and development: Cognition, morality, and identity, 3rd ed. New York, NY: Psychology Press.

Moshman, D. (2011b). Adolescents and their teenage brains. Human Development, 54, 201-203. DOI: 10.1159/000330300

Moshman, D. (2011c, May 17). The teenage brain: Debunking the 5 biggest myths. Huffington Post. http://www.huffingtonpost.com/david-moshman/ adolescents-and-their-tee b $858360 . h t m l$ 
Müller, U., Carpendale, J. I. M., \& Smith, L. (Eds.). (2009). The Cambridge companion to Piaget. New York, NY: Cambridge University Press.

Nichols, S. L., \& Good, T. L. (2004). America's teenagers-myths and realities. Mahwah, NJ: Erlbaum.

Overton, W. F. (2006). Developmental psychology: Philosophy, concepts, and methodology. In W. Damon, R. M. Lerner (Series Eds.) \& R. M. Lerner (Vol. Ed.), Handbook of child psychology: Vol. 1. Theoretical models of human development (6th ed., pp. 18-88). Hoboken, NJ: Wiley.

Overton, W. F. (2010). Life-span development: Concepts and issues. In R. M. Lerner (Ed-in-chief) \& W. F. Overton (Vol. Ed.), The handbook of life-span development: Vol. 1. Cognition, biology, and methods (pp. 1-29). Hoboken, NJ: Wiley.

Paus, T. (2009). Brain development. In R. M. Lerner \& L. Steinberg (Eds.), Handbook of adolescent psychology, Vol. 1 (3rd ed., pp. 95-115). Hoboken, NJ: Wiley.

Quadrel, M. J., Fischhoff, B., \& Davis, W. (1993). Adolescent (in)vulnerability. American Psychologist, 48, 102-116.

Sercombe, H. (2010). The gift and the trap: Working the "teen brain" into our concept of youth. Journal of Adolescent Research, 25, 31-47. DOI: 10.1177/0743558409353065

Sherrod, L. R., Torney-Purta, J., \& Flanagan, C. A. (Eds.). (2010). Handbook of research on civic engagement in youth. Hoboken, NJ: Wiley.

Smetana, J. G. (2011). Adolescents, families, and social development: How teens construct their worlds. Malden, MA: Wiley-Blackwell.

Smetana, J. G., \& Villalobos,M. (2009). Social cognitive development in adolescence. In R.M. Lerner \& L. Steinberg (Eds.), Handbook of adolescent psychology, Vol. 1 (3rd ed., pp. 187-228). Hoboken, NJ:Wiley.

Spear, L. (2010). The behavioral neuroscience of adolescence. New York, NY: Norton.

Umeh, K. (2009). Understanding adolescent health behaviour: A decision making perspective. New York, NY: Cambridge University Press.

Witherington, D. C. (2007). The dynamic systems approach as metatheory for developmental psychology. Human Development, 5O, 127-153. DOI: 10.1159/ooo100943

Witherington, D. C. (2011). Taking emergence seriously: The centrality of circular causality for dynamic systems approaches to development. Human Development, 54, 66-92. DOI: 10.1159/000326814 